\title{
Complications after Self-injection of Chemical Substances into the Penis
}

\author{
ORSOLYA MARTHA A,2, IOAN SCARNECIU 3,4 , CAMELIA C. SCARNECIU ${ }^{3,4}$, VERONICA GHIRCA ${ }^{2 *}$, OLIVER VIDA ${ }^{1,2}$, MIHAI BADEA ${ }^{2}$, \\ LAURIAN MAXIM ${ }^{3,4}$, CATALIN MISARCA ${ }^{3,4}$, SORIN LUPU ${ }^{4}$, CIPRIAN TODEA MOGA ${ }^{1,2}$ \\ 'Urology Clinic, Mures County Hospital, 50 Gheorghe Marinescu Str., 540136, Targu Mures, Romania \\ 2University of Medicine, Pharmacy, Science and Technology, 38 Gheorghe Marinescu Str., 540139, Targu Mures, Romania \\ 3University of Medicine and Pharmacy Transilvania, 56 Nicolae Balcescu Str., 500019, Brasov, Romania \\ ${ }^{4}$ Clinical Emergency County Hospital, 25-27 Bucuresti Road, 500326, Brasov, Romania
}

Illicitinjection of different, exogenous substances into the penis for enlargement purposes is a practice that is still met in some of the Eastern countries of Europe. Our study conducted over a period of 3 years (20162019) at the Urology Clinic from Tirgu Mures, highlights the complications that can occurre after the injection of different chemical substances, such as liquid paraffin, vaseline, olive oil etc., into the penile subcutaneous tissue with the purpose of augmentation. We report 7 patients presenting several complications some of them severe such as: extensive fibrosis, ulceration, penile deformity, erectile dysfunctions, requiring different surgical procedures. The surgical technique was selected according to the extension of fibrosis or necrosis:excision of the necrotic, fibrotic tissue, scrotal skin flap reconstruction etc. In our study, we found 7 patients that accomplished the inclusion criteria. Five patients were diagnosed with penile fibrosis after selfinjection of Kanamycin, and two of the patients had the same diagnosis after self-injection of Vaseline. In 2 patients, the postoperative outcome was complicated by wound dehiscence and necrosis, requiring other reconstructive surgeries, and in 5 patients postoperative recovery was a favorable one, without significant complications. In the management of complications of illicit injection of different, exogenous substances into the penis, penile tunneling with scrotal flap technique seems to offer good results due to the vascular flap, allowing faster wound healing and a superior aesthetic and functional result.

Keywords: penis fibrosis, Kanamycin, Vaseline, scrotal flap

Over the time, men revealed a particular interest to the aspect of their genitals, including the size of the penis. Regardless of the real size, a man can be disturbed by the thought that the size of his penis is not enough to satisfy his partner or be satisfied himself [1]. These excessive concerns could be unfounded and could represent social anxiety or a clinical problem, such as erectile dysfunction [1].

Penile implants and injections of exogenous substances are described for about 1500 years [2]. In 1899, Robert Gersuny prescribed medical procedures involving mineral oils used for cosmetic purposes such as wrinkles, baldness, muscle enlargement, breast augmentation and penis enlargement [2].

Most men looking for medical procedures in order to increase the size of the penis, have a normal and perfectly functional organ [1]. Over the time, a varied chemical composition of oils were injected into the penile subcutaneous tissue with the intention of augmentation and a lot of adverse effects had been reported since 1906, such as subcutaneous nodules, penile deformation, phimosis, skin necrosis, infections $[3,4]$, erectile dysfunction and inability to support sexual activities [5].

Improving the circumference of the penis after the selfinjection of Vaseline is a clandestine practice even today [6]. After the self-injection of this substance, the complications that occur are similar to other chemical substances injected and require surgical reconstruction to solve them. The first paraffin injection was reported in 1899 in a young man who injected paraffin into the scrotum after a bilateral orchiectomy for genital tuberculosis [7].

Chemical substances such as mineral oil, paraffin, vaseline and hyaluronic acid are used unauthorized, in an illicit manner for injection in our days, despite the reported adverse effects [5].

After the reports that described the side effects, these treatment procedures were omitted from traditional medicine, but they are performed either by non-medical staff or by self-injection [2]. Complications resulting from the injection of foreign substances are caused by the deficiency of enzymes that metabolize exogenous oils in human tissues that lead to the formation of sclerosis granuloma [2] or paraffinoma in case of liquid paraffin injection.

Sclerosis granuloma is a specific granulomatous reaction of the fat tissue that occur after the injection of chemical substances [5]. In these cases, the treatment used is the partial or total excision of granulomas, with or without the use of flaps for the reconstruction of the tegument [5]. Penile plasty represents a surgical procedure that requires the excision of injured tissue and in most of the cases, the use of flaps from distant areas [8].

\section{Experimental part \\ Material and method}

The study was conducted over a period of 3 years (20162019) in the Urology Clinic from Tirgu Mures, Romania, and included patients who self-injected chemical substances in subcutaneous tissue of the penis, with the purpose of augmentation. In most of the cases, patients were conscious of the risks of injection of these substances and the dangerous complications they are exposed to.

In our study, we found 7 patients who accomplished the inclusion criteria. Five patients were diagnosed with penile fibrosis after self-injection of Kanamycin, one of the patients had the same diagnosis after self-injection of 
Vaseline and one after Paraffin oil. In 2 patients, the postoperative outcome was complicated by wound dehiscence and necrosis of the flap, requiring others reconstructive surgeries, and in 5 patients the postoperative recovery was favorable, withoutsignificant complications.

The average age of the patients was 26.28 years old with limits between 18 and 43 years. The average period from the injection of thechemical substances until the occurrence of the complications was 9.14 months with limits between 1 month and 3 years. Patients' complaints were penile pain, deformation, erectile dysfunction and inability to support a sexual intercourse.

Besides the well-known possible complications, patients reported that they performed self-injection of that substances for cosmetic reasons, in most of the cases, and to improve their sexual activity. The complications found in our patients after self-injection of the substances were: penile fibrosis in all the cases, skin necrosis in 4 cases, infection of the skin lesions in 3 cases, subcutaneous nodules in 4 cases, penile deformation and phimosis in all the cases. Confidentiality has been respected concerning the collected data.

\section{Surgical technique}

In the first step of the procedure, a longitudinal incision was made in the lower part of the scrotum, with the excision of the fibrotic tegument from the base to the gland of the penis. A scrotal tunnel was formed between the skin layer and the Dartos layer. The penis was inserted under the scrotal skin and was exteriorized by the distal opening of the tunnel [8]. In the second step, a bilateral incision of the scrotal skin was performed at the base of the penis and the penis was separated from the remaining scrotal skin [8]. If there is tegument deficiency after the excision of the fibrotic tissue, scrotal flap remains the best option for penis plasty, due to vascularization, tissue characteristics and anatomical proximity of the penis [8].

\section{Results and discussions}

Penile reconstructive surgery is in continuous development, but remains an anatomic, functional and aesthetic challenge especially in cases with severe complications after illicit, self-injection [9]. The most used self-injected chemical substances are mineral oils, vaseline, paraffin oils and kanamycin $[5,6]$. In these abovementioned cases, reconstruction with scrotal flap technique seems a good choice, if it's not possible, skin grafts may be used from other parts of the body [9]. The objective of the surgical reconstruction is to achieve a functional genital organ and acceptable from aesthetically point of view [10].

It is well known and demonstrated by clinical and experimental studies that exposure to chemical substances also represent a risk factor for toxicity [11-13], or future development of tumors [14-16], in differentorgans like bladder, kidney etc [17-20], so a long follow up of the patients with self-injection should be required. In most of the cases the patients who practice illicit self-injection of those substances are young and they present to the doctor due to the complications that can appear during the following period (Table1).

Mineral oil is a fluid with high viscosity and the patients self-inject it into the subcutaneous tissue of the penis for augmentation [5]. Their motivation varies from the desire to increase the length or circumference of the organ, and to increase the sexual pleasure [5]. We had one patient who injected Paraffin oil and one with Vaseline and in both cases the outcome after the surgery was complicated by wound dehiscence and necrosis of the tegumentflap. Also, the complications appeared quickly, after 1 month. The

\begin{tabular}{|c|c|c|c|c|}
\hline Case & Age & Substance injected & Lasting time & Complications \\
\hline 1 & 32 & Kanamycin & 7 months & $\begin{array}{l}\text { Fibrosis } \\
\text { Necrosis } \\
\text { Subcutaneous nodules } \\
\text { Penile deformation } \\
\text { Phimosis }\end{array}$ \\
\hline 2 & 22 & Kanamycin & 10 months & $\begin{array}{l}\text { Fibrosis } \\
\text { Necrosis } \\
\text { Infection of the tegument } \\
\text { Phimosis } \\
\text { Penile deformation }\end{array}$ \\
\hline 3 & 20 & Kanamycin & 3 years & $\begin{array}{l}\text { Fibrosis } \\
\text { Necrosis } \\
\text { Subcutaneous nodules } \\
\text { Infection of the tegument } \\
\text { Phimosis } \\
\text { Penile deformation }\end{array}$ \\
\hline 4 & 43 & Kanamycin & 5 months & $\begin{array}{l}\text { Fibrosis } \\
\text { Subcutaneous nodules } \\
\text { Phimosis } \\
\text { Penile deformation }\end{array}$ \\
\hline 5 & 24 & Kanamycin & 4 months & $\begin{array}{l}\text { Fibrosis } \\
\text { Necrosis } \\
\text { Infection of the tegument } \\
\text { Phimosis } \\
\text { Penile deformation }\end{array}$ \\
\hline 6 & 18 & Paraffin oil & 1 months & $\begin{array}{l}\text { Fibrosis } \\
\text { Phimosis } \\
\text { Penile deformation }\end{array}$ \\
\hline 7 & 25 & Vaseline & 1 months & $\begin{array}{l}\text { Fibrosis } \\
\text { Subcutaneous nodules } \\
\text { Phimosis } \\
\text { Penile deformation }\end{array}$ \\
\hline
\end{tabular}

Table 1

PATIENTS' DATA 
evolution after the surgery in patients who injected Kanamycin was better, but the complications were comparable with the other oils.

Consequences following injection are devastating, affecting the sexual and cosmetic function of the penis [2]. Complications can vary depending on the amount of substance that has been administered, personal tolerance, and hygiene conditions [6].

Sclerosis granuloma is the secondary result of selfinjection with this oil and is associated with impotence, painful sexual intercourse or inability to perform the vaginal penetration [5]. All the patients included in the study presented penile deformation and phimosis. Also, following the injection of these substances, intra-cavernous fibrosis, adverse reactions ranging from subcutaneous nodules to intra-cavernous fibrosis and penile plaques leading to erectile dysfunction have been reported [21-24]. In our study, subcutaneous nodules were found in 4 cases. Penile necrosis of the tegument was associated with infection of the lesions in 3 cases and caused severe pain sexual dysfunction and inability to sustain a proper and satisfying intercourse.

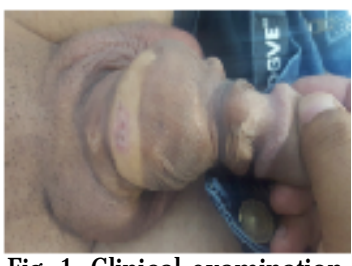

Fig. 1. Clinical examination before surgery

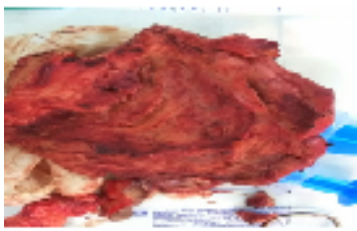

Fig. 3. Fibrotic tissue

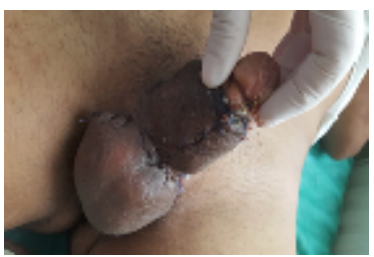

Fig. 5. The penis is separated from the remaining scrotal skin in the second step of the surgery

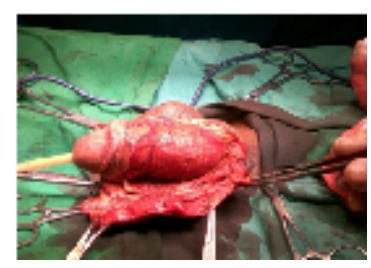

Fig. 2. Excision of the fibrotic tissue

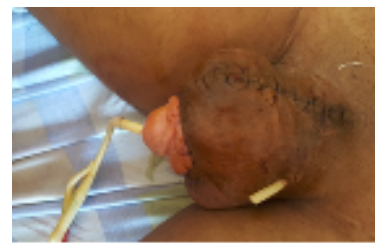

Fig. 4. Insertion of the penis under the scrotal skin in first step of the surgery

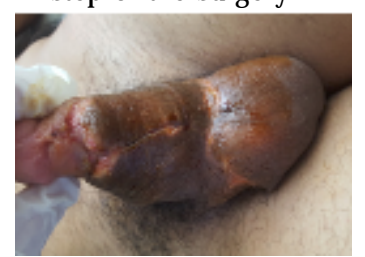

Fig. 6. The outcome after 4 weeks from the surgery
The surgical treatment is difficult, but the excision of chemical material and the fibrous tissue is a satisfactory procedure, with good long-term cosmetic and functional results [5].

\section{Conclusions}

Illicit self-injection of chemical substances into the penile subcutaneous tissue can lead to severe complications, from fibrosis, necrosis of the tegument, infections to erectile dysfunctions. The proper treatment option for penile fibrosis after self-injection of chemical substances is asurgical one which implies different techniques of penile reconstruction with or without flaps. Penile tunneling with scrotal flap technique has good results due to the vascular flap, allowing faster wound healing and a superior aesthetic and functioning result.

\section{References}

1.COSKUNER, E.R., CANTER, H, I., J Cutan Aesthet Surg, 5, no. 3, 2012, p. 198.

2.SVENSOY, J.N., TRAVERS, V., SLOTH OSTHER, P. ., World J Urol, 36, no. 1, 2018, p. 135.

3.RADULESCU, A., MADAN, V., AUNGURENCI, A., BRATU, O., FARCAS, C., DINU, M., MISCHIANU, D., Romanian J ournal of Military Medicine, 118, no. 3, 2015, p. 20-22.

4.SPINU, D., BRATU, O., POPESCU, R., MARCU, D., RADULESCU, A., MISCHIANU, D., Romanian Journal of Military Medicine, 118, no. 3, 2015, p. 12-15.

5.BJURLIN, M.A., CARLSEN, J., GREVIOUS, M., et al., J Clin Aesthet Dermatol, 3, no. 9, 2010, p. 41.

6.BAJ ORY, Z., MOHOS, G., ROSECKER, A., et al. J Sex Med. 10, no. 4, 2013, p. 1170.

7.DELLIS, A.E., NASTOS, K., MASTORAKOS, D., et al., Arab J Urol. 15, no. 4,2017, p. 387.

8.ZIYLAN, O., ACAR, O., BURC, C., et al., Turk J Urol, 41, no. 4, 2015, p. 235.

9.SCHECHTER, L.S., SAFA, B., Clin Plast Surg, 45, no. 3, 2018, p. 387. 10.GARAFFA, G., SANSALONE, S., RALPH, D.J., Asian J Androl., 15, no. 1,2013, p. 16.

11.DIACONU, C.C., BALACEANU A., COSTACHE, C., J ournal of Hepatology, 60, Supplement 1, 2014, S515-S515.

12.DIACONU, C.C., ARSENE, D., PARASCHIV, B., BALACEANU, A., BARTOS, D., Acta Endocrinologica, IX, no. 4, 2013, p. 637-642.

13.BALACEANU, A., DIACONU, C.C., ARON, G., Medical Ultrasonography, 16, no. 2, 2014, p. 172-174.

14.DIACONU, C.C., ARSENE, D., BALACEANU, A., BARTOS, D., Romanian J ournal of Morphology and Embryology, 55, no. 3, 2014, p. 973-976.

15.PARASCHIV, B., TOMA, C.L., DIACONU, C.C., Archivos de Bronconeumología, 49, no. 7, 2013, pp. 315-316.

16.BALACEANU, A., DIACONU, C., MATEESCU, D., STANICA, A., Medical Ultrasonography, 12, no. 4, 2010, p. 345-348.

17.BALAN, D., MARTHA, O., CHIBELEAN, C., TATARU, S., VOIDAZAN, S., SIN, A., MATEI, V.D., VARTOLOMEI, M.D., LUCARELLI, G., CIOFFI, A., DEL GIUDICE, F., DE BERARDINIS, E., BORDA, A., BUSETTO, G.M., PYTEL, A., PORAV-HODADE, D., Medicine, 87, no. 16, 2018, e0522. 18.ABDEL-DAIM, M.M., EL-TAWIL, O.S., BUNGAU, S.G., ATANASAOV, A.G., Oxid Med Cell Longev, 2019, ID 4179676, 2019. https://doi.org/ 10.1155/2019/4179676.

19.ABDEL-DAIM, M.M., ABO-EL-SOOUD, K., ALEYA, L., BUNGAU, S.G., NAJDA, A., SALUJA, R., Oxid Med Cell Longev, 2018, ID 6276438, 2018. https://doi.org/10.1155/2018/6276438

20.ABDEL-DAIM, M.M., AHMED, A., IJ AZ, J., ABUSHOUK, A.I., AHMED, H., NEGIDA, A., ALEYA, L., BUNGAU, S., Environ Sci Pollut Res, 26, no. 8, 2019, p. 8080. https://doi.org/10.1007/s11356-019-04249-4.

21.GONZALEZ-CADAVID, N.F., J Sex Med, 6, no. 3, 2009, p. 353.

22.SPINU, D., BRATU, O., MARCU, D., MISCHIANU, D., HUICA, R., SURCEL, M., MUNTEANU, A., SOCEA, B., BODEAN, O., URSACIUC, C., Rev Chim (Bucharest), 69, no. 3, 2018, p. 645-649.

23.SOCEA, L.I., VISAN, D.C., BARBUCEANU, S.F., APOSTOL, T.V., BRATU, O.G., SOCEA, B., Rev Chim (Bucharest), 69, no. 4, 2018, p. 795-797.

24.TIGLIS, M., NEAGU, T.P., ELFARA, M., DIACONU, C.C., BRATU, O.G., VACAROIU, I.A., GRINTESCU, I.M., Rev Chim (Bucharest), 69, no. 10, 2018, p. 2877-2880.

$\overline{\text { Manuscript received: } 6.02 .2019}$ 